\title{
The role of Gut Microbiota in the development of obesity and Diabetes
}

\author{
Othman A. Baothman ${ }^{1 \dagger}$, Mazin A. Zamzami ${ }^{1 \dagger}$, Ibrahim Taher $^{2}$, Jehad Abubaker ${ }^{3^{*}}$ and Mohamed Abu-Farha ${ }^{3^{*}}$ (D)
}

\begin{abstract}
Obesity and its associated complications like type 2 diabetes (T2D) are reaching epidemic stages. Increased food intake and lack of exercise are two main contributing factors. Recent work has been highlighting an increasingly more important role of gut microbiota in metabolic disorders. It's well known that gut microbiota plays a major role in the development of food absorption and low grade inflammation, two key processes in obesity and diabetes. This review summarizes key discoveries during the past decade that established the role of gut microbiota in the development of obesity and diabetes. It will look at the role of key metabolites mainly the short chain fatty acids (SCFA) that are produced by gut microbiota and how they impact key metabolic pathways such as insulin signalling, incretin production as well as inflammation. It will further look at the possible ways to harness the beneficial aspects of the gut microbiota to combat these metabolic disorders and reduce their impact.
\end{abstract}

\section{Background}

Obesity and its associated disorders have reached an alarming stage worldwide. The last decades have experienced an exponential increase in the number of people suffering from obesity and its associated disorders such as T2D [1-7]. Sedentary lifestyle and increased food consumption has been considered the main underlying causes for this obesity epidemic [8-10]. Environmental and genetic factors have also been implicated including changes in the gut microbiota to play a role in the development of metabolic disorders [11-17]. Gut microbiota describes all organisms living in the gastrointestinal (GI) tract. The majority of these organisms reside in the large intestine. These bacteria play important physiological role in vital processes such as digestion, vitamin synthesis and metabolism amongst others. Even though the exact mechanism linking gut microbiota to obesity is far from being very well understood, it's well established that gut microbiota can increase energy production from diet, contribute to low-grade inflammation and regulate fatty acid tissue composition $[11,18,19]$. These processes as well as others have been proposed as the link

\footnotetext{
* Correspondence: jehad.abubakr@dasmaninstitute.org;

mohamed.abufarha@dasmaninstitute.org; mafarha@gmail.com

${ }^{\dagger}$ Equal contributors

${ }^{3}$ Biochemistry and Molecular Biology Unit, Dasman Diabetes Institute,

Dasman, P.O. Box 118015462 Kuwait City, Kuwait

Full list of author information is available at the end of the article
}

between obesity and gut microbiota. However, the exact contribution of gut microbiota to the development of obesity and diabetes is not very clear due to many reasons including the complexity and diversity of gut microbes, ethnic variation in studied populations and large variations between individuals studied $[14,20]$. Nonetheless, modulation of gut microbiota holds a tremendous therapeutic potential to treat the growing obesity epidemic especially when combined with diet and exercise [21-23]. This review shed some light on the recent work linking gut microbiota with obesity and diabetes and looks at possible ways to modulate gut microbiota to control the spread of obesity and diabetes.

\section{Origin and composition of gut micribiota}

The human body contains trillions of microorganisms that inhabit our bodies during and after birth [24-26]. During the pregnancy, infant's intestinal tract is free of microbes until exposed to maternal vaginal microbes during normal birth [27]. Infants born through Caesarian section are exposed to maternal skin bacteria altering their bacterial gut composition [27]. Feeding represents another source of microorganisms where breast fed babies have different gut microbiota composition than formula fed babies [27]. Introduction of solid food represents another shift in the composition of babies gut microbiota [28]. After that, gut microbiota remains relatively unchanged until old age where the composition changes again. Adult 
humans have more than 10 times the number of bacterial cells than the cells constituting the human body. Majority of microbiota in the GI tract are bacteria, nevertheless, viruses fungi and other microorganisms are still present [14]. Even though, individuals have unique microbiota composition, gut microbiota is mainly members of four phyla (Firmicutes, Bacteroidetes, Actinobacteria and Proteobacteria) [19]. As shown in Table 1, the large intestine contains the highest number of bacteria containing over $10^{11}$ bacteria per gram of intestinal content. The mouth contains $10^{12}$ followed by the Ileum containing $10^{8}-10^{9}$ bacteria [29]. On the other hand, the jejunum harbors $10^{5}-10^{6}$ while the stomach has the least number of bacteria $10^{3}-10^{4}$ [29]. Even though we are still far from identifying, let alone characterizing all bacteria in our system, advancing molecular biology techniques such as next-generation sequencing has tremendously contributed to our understanding of the gut microbiota [30]. The use of gnotobiological methods to breed mice in a sterile environment provided an invaluable tool to understand the role of infecting controlled bacterial cultures and defined bacterial strains into animals. Studying their effect through various genomic and proteomic tools [29].

\section{Factors affecting gut microbiota composition}

Composition of gut microbiota is affected by many factors such as diet, disease state, medications as well as host genetics to name a few. As a result, the composition of the gut microbiota is constantly changing affecting the health and well-being of the host such as disease state as well as the use of various medicines such as antibiotics (Fig. 1). The effect of antibiotics on gut microbiota is well documented showing a long term reduction in bacterial diversity after use of antibiotics. Thuny et al has shown that the use of intravenous treatment by vancomycin plus gentamycin has been associated with a major and significant weight gain [31]. Link between antibiotics and weight gain is also well documented in infants as well, for example, Saari et al has linked antibiotic exposure during the first 6 months of age to weight gain in healthy children [32]. Furthermore, Studies have shown that the use of antibiotics will cause a decline in the bacterial diversity, stereotypic declines as

Table 1 Number of bacteria in different components of the gastrointestinal tract

\begin{tabular}{ll}
\hline Digestive Tract & Number of Bacteria \\
\hline Mouth & $10^{12}$ \\
Stomach & $10^{3}-10^{4}$ \\
Jejunum & $10^{5}-10^{6}$ \\
Terminal Ileum & $108-109$ \\
Large Intestine & $10^{11}$ Per gram of intestinal contents \\
\hline
\end{tabular}

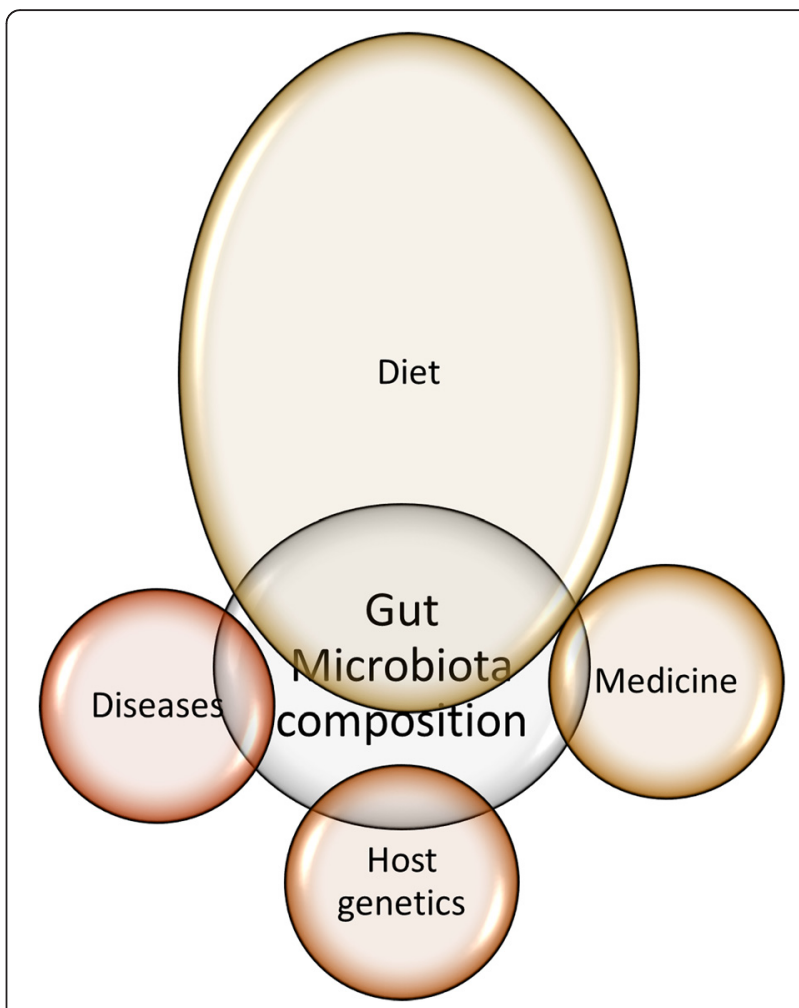

Fig. 1 A diagram showing main factors affecting the gut microbiota composition highlighting the great impact of diet on this composition

well as increased abundances of certain taxa [33-43]. On the other hand, recovery of normal microbiota from certain antibiotic treatment can be long depending on the type of antibiotic and its spectrum [44]. Strong and broad spectrum antibiotics such as clindamycin can have longer affects persisting up to 4 years as suggested by some studies [45]. Moreover, the stress caused by the disruption of normal flora after antibiotic treatment facilitates the transfer of antibiotic resistance genes to virulent species leading to increased drug resistance [44]. These studies highlight the importance of better understanding of the role antibiotics play in modulating gut microbiota and their contribution to weight gain and potentially loss as well as other diseases.

Finally, the main contributor to the diversity of the gut microbiota is diet [46-52]. It has been suggested that changes in the diet can account for $57 \%$ of the variations in microbiota compared to genetic variations in host that can only account for $12 \%$ [53]. The effect of diet on microbiota composition is prominently observed as early as during breast and formula feeding as mentioned above. For example, level of Bifidobacteria spp. is higher in breast-fed babies compared to formula fed babies [54-59]. Formula-fed babies on the other hand have a more diverse microbiota with higher levels of Bacteroids spp. and Lactobacillus spp. [58]. Moreover, probiotics and 
prebiotics are among the most dietary strategies established for controlling the composition and metabolic activity of gut microbiota. Probiotics are non-pathogenic microorganisms used as food ingredients to benefit the hosts' health. Jones et al investigated the effect of a bile salt-hydrolyase Lactobacillus reuteri strain in hypercholesterolemic individuals. They found this strain can significantly lower the low-density lipoprotein cholesterol (LDL-C) [60]. Also they proposed the role of nuclear receptor farnesoid X receptor (FXR) as transactional factor in reducing fat absorption from intestine. Furthermore, prebiotics are fermented dietary fibers have been shown to impact the host by specifically stimulating changes in the composition and/or activity of bacteria in the colon, and thus improving the hosts' health [61]. Lactulose, resistant starch and inulin are the most prebiotic compounds used by the food industry to modify the composition of gut microbiota to benefit human health. These have been shown to mostly target bifidobacteria and lactobacilli $[62,63]$. Prebiotics are carbohydrate-like compounds, such as lactulose and resistant starch, and have been used in the food industry to modify the composition of the microbiota species to benefit human health in recent years [62]. Inulin is one type of prebiotics. These prebiotics mostly target bifidobacteria and lactobacilli, which are two kinds of probiotics [63]. Recent research suggested that combining both prebiotics and probiotics, namely synbiotics can also fight obesity [64].

A number of studies have shown tight connection between diet and microbiota indicating how the composition of different diets will directly impact gut microbiota $[47,49,51,52]$. In an earlier study, Turnbaugh et al used humanized mice that were generated by transplanting human feces into germ-free mice to study the effect of diet on microbiota [65]. Switching mice from low-fat, plant polysaccharide-rich diet to so call "Western diet", a highfat and sugar diet, altered the composition of the microbiota within a single day [65]. Mice fed with the Western diet had increased number of Erysipelotrichi class of bacteria within the Firmicutes phylum and reduced Bacteroides spp. Similarly mice fed a vegetarian diet, rich in dietary fibers, had lower counts of Bacteroides spp. E. Coli and other bacteria compared to the controls. Table 2 gives a summary of recent studies looking at changes in gut microbiota after consuming various types of diets that have various levels of sugar, fat and protein such as western diet, vegetarian and Calorie restricted diet.

\section{Obesity and gut microbiota}

Due to the exponential increase in obesity rates and its associated complications such as diabetes in the past few decades, tremendous attention has been given to understanding underling mechanism. Albeit these tremendous
Table 2 The effect of various diets on the composition of gut microbiota diversity

\begin{tabular}{|c|c|}
\hline Diet Type & Effect on bacteria \\
\hline \multirow[t]{4}{*}{ High Fat Diet } & $\begin{array}{l}\text { Decrease of genera within the class Clostridia } \\
\text { in the ileum. Increase Bacteroidales in large } \\
\text { intestine [130] }\end{array}$ \\
\hline & $\begin{array}{l}\text { Increase Lactobacillus spp., Bifidobacterium } \\
\text { spp., Bacteroides spp., and Enterococcus spp. } \\
\text { Decrease Clostridium leptum and } \\
\text { Enterobacter spp. [131] }\end{array}$ \\
\hline & $\begin{array}{l}\text { Increase Firmicutes to Bacteriodetes ratio. And } \\
\text { increased Enterobecteriaceae [132] }\end{array}$ \\
\hline & $\begin{array}{l}\text { increase Bacteroidales, Clostridiales and } \\
\text { Enterobacteriales [133] }\end{array}$ \\
\hline \multirow[t]{3}{*}{ Vegetarian Diet } & $\begin{array}{l}\text { Decrease Acteroides spp., Bifidobacterium } \\
\text { spp., Escherichia coli and Enterobacteriaceae } \\
\text { spp. [134] }\end{array}$ \\
\hline & $\begin{array}{l}\text { Decrease Enterobacteriaceae and increase } \\
\text { Bacteroides [135] }\end{array}$ \\
\hline & $\begin{array}{l}\text { Increase Bacteroidetes, and decrease } \\
\text { Firmicutes and Enterobacteriaceae [136] }\end{array}$ \\
\hline Calorie restricted & Decrease Firmicutes to Bacteroidetes ratio [137] \\
\hline
\end{tabular}

efforts and the identification of candidate genes and mutations in studies like genome wide association studies (GWAS), full understanding is still lacking. During the last decade new studies have emerged suggesting a role for gut microbiota in the development of obesity and diabetes [11, 66-77]. More studies have been published showing a wide range role of gut microbiota in processes like energy homeostasis, blood circulation and autoimmunity to list a few. Early studies showed that obese mice as well as humans had different gut microbiota composition compared to lean. A number of studies showed an increase in bacteria from the Firmicutes phyla and a decrease in the Bacteroidetes phyla that is believed to be associated with increased energy absorption from food and increased low-grade inflammation $[15,17]$. However, other studies showed no difference between these two phyla in lean and obese subjects, highlighting the need for focusing further on specific species within those groups rather than comparing them at the phyla level. Another example for the role of microbiota in obesity has been seen with patients undergoing Rouex-en-Y gastric bypass. After the surgery, patients observe dramatic metabolic improvement that cannot be explained by the caloric restriction and the weight loss alone. Changes in gut microbiota have been shown to play a role in this improvement as a shift in bacterial population has been observed in a number of studies [18-20, 76, 78-86]. In order to demonstrate the role of bariatric surgery in the changes of the gut microbiota, Liou et al showed that fecal transplantation from RYGB-treated mice into germ-free mice lead to weight loss and decreased fat mass in mice [87]. 
Gut microbiota contributes to energy metabolism through the production of SCFA that are produced by colonic fermentation which involves the anaerobic breakdown of dietary fiber, protein and peptides. SCFA are bacterial waste products that are produced by the bacteria to balance the redox state in the gut. Most abundant SCFA species are acetate, propionate, and butyrate. Acetate and propionate are mostly produced by Bacteroidetes phylum, while butyrate is produced by the Firmicutes phylum. They have been shown to exert beneficial effects on body weight, glucose homeostasis and insulin sensitivity. Gao et. al. showed that butyrate dietary supplementation reduces diet-induced insulin resistance in mice possibly through increasing energy expenditure and mitochondria function [88]. Butyrate and propionate were protective against diet-induced obesity [89]. Oral administration of acetate also improved glucose tolerance [90]. On the contrary to its proposed beneficial effect in diet induced obesity, cecal and fecal SCFA levels have been shown to be higher in genetically obese ob/ob mice and obese human subjects [16, 91, 92]. It has been suggested that this increase in SCFA is due to decreased colonic absorption with obesity [91].

SCFA can also act as signaling molecules and activate various pathways such as the activation of the AMPactivated protein kinase (AMPK) in liver and muscle tissues that triggers the activation of key factors involved in cholesterol, lipid, and glucose metabolism peroxisome proliferator-activated receptor-gamma coactivator 1 alpha (PGC-1 $\alpha)$, Peroxisome proliferator-activated receptor gamma (PPAR $\gamma$ ), and Liver $\mathrm{X}$ receptors (LXR) [93]. In addition SCFA have been also shown to activate Glucagon-like peptide-1 (GLP-1) through G-protein coupled receptor 43 (GPR43) which is also known as free fatty acid receptor 2 (FFAR2) [94, 95]. FFAR2 is one of the SCFA receptors and that has been shown to be activated by acetate and propionate followed by butyrate $[96,97]$. Mice lacking the FFAR2 receptor were obese while its overexpression in adipose exhibited leanness under normal conditions [98]. It's believed that these phenotypes were mediated by gut microbiota produced SCFA since these mice strains did not show the same phenotypes in mice grown under germ-free conditions or when treated with antibiotics [99]. The second SCFA receptor is GPR41, also called FFAR3 that shares $33 \%$ amino acid sequence identity with FFAR2 and is activated mainly by propionate and butyrate [89]. Similar to FFAR2, FFAR3 is capable of inducing the gut hormone peptide YY (PYY) and GLP-1. It can also improve insulin signaling through SCFA produced by gut microbiota [100, 101].

Gut microbiota was also shown to play a role in the regulation of bile acids and cholesterol metabolism in both humans and animals [102]. Bile acids are synthesized in the liver by a multistep pathway. It can also act as an emulsifying agent in the intestine; helping to prepare dietary triacylglycerol and other complex lipids for degradation by pancreatic digestive enzymes. Before bile acids leave the liver, they convert into bile salts by conjugating to either glycine or taurine then re-absorbed in the ileum. A small amount of bile acids lost in fecal excretion via the action of intestinal bacteria. It was suggested that the possible role of gut microbiota in controlling bile acid and cholesterol metabolism might be induced by the up-regulation of transcription factors that link it to nutritional-induced inflammation, lipid absorption and de novo lipogenesis [102].

Low grade inflammation is a hallmark of obesity and T2D. Productions of pro-inflammatory cytokines are coordinated Via the Toll-like receptors (TLRs) and the master regulator of key inflammatory cascades the nuclear factor kappa (NF-kB) [103-106]. These pathways have been shown to be activated by the production of lipopolysaccharides (LPS) that are major component of the outer membrane of Gram-negative bacteria that is produced in the gut [106]. Higher LPS levels have been associated with increased fat intake. It was also observed in obese mice models. It has been proposed that dietary fat mediated the absorption of LPS linking them to obesity. In fact, it has been demonstrated that adding LPS to normal-diet induced insulin-resistance and lead to weight gain. It has been also shown that LPS binds to TLR4 receptor on macrophages and activate the production of inflammatory markers in a process that has been linked to impairing pancreatic $\beta$-cell by suppressing insulin secretion and decreasing gene expression of Pancreatic And Duodenal Homeobox 1 (PDX1) [107].

\section{Diabetes and gut microbiota}

It's becoming increasingly evident that gut microbiota is contributing to many human diseases including diabetes both type 1 and type 2 . Type 1 diabetes (T1D) is an autoimmune disease that is caused by the destruction of pancreatic $\beta$-cells by the immune system. Even though T1D is mainly caused by genetic defect, epigenetic and environmental factors have been shown to play an important role in this disease. Higher rates of T1D incidence have been reported in recent years that are not explained by genetic factors and have been attributed to changes in our lifestyle such diet, hygiene, and antibiotic usage that can directly affect microbiota [108]. It has been shown that diabetes incidence in the germ free non-obese diabetic subjects or patients (NOD) was significantly increased which is in line with the observation that the rates of T1D is higher in countries with stringent hygiene practices [108]. Similarly comparison of the gut microbiota composition between children with high genetic risk for T1D and their age matched 
healthy controls showed less diverse and less dynamic microbiota in the risk group [109]. In the Diabetes Prevention and Prediction (DIPP) study it was shown that new-onset T1D subjects had different gut microbiota composition than controls [110]. They showed that in the control group, mucin synthesis was induced by lactate- and butyrate-producing bacteria to maintain gut integrity while mucin synthesis was prevented by the non-butyrate-producing lactate-utilizing bacteria leading to $\beta$-cell autoimmunity and T1D [110]. In another study linking intestinal microbes with the innate immune system Wen et al used Myd88 knockout to show that specific-pathogen free (SPF) NOD mice lacking MyD88 protein do not develop T1D [111]. MyD88 is a mediator for multiple innate immune receptors such as TLR4 that recognize microbial stimuli [112]. Many other studies confirmed the differences observed in gut microbiota composition between T1D and their matched health controls highlighting the need for better understanding of the role that these bacteria may play in the development of this disease [108, 109, 113-122].

The link between T2D and gut microbiota is becoming clearer with more studies showing the involvement of microbiota in obesity and their role in insulin signaling and low grade inflammation as discussed in the previous section. The effect of microbiota on T2D has been proposed to be mediated through mechanisms that involve modifications in the secretion butyrate and incretins [94, 95, 101, 123, 124]. Qin et al showed that T2D patients had moderate degree of gut microbial dysbiosis, a decrease in universal butyrate-producing bacteria and an increase in opportunistic pathogens [125]. Similar data were reported by other studies highlighting the role of these bacteria in regulating important T2D pathways such as insulin signaling, inflammation and glucose homeostasis [13, 18, 99, 124-129]. On the other hand, gut microbiota has been shown to affect the production of key insulin signaling molecules such as GLP-1 and PYY through SCFA and its binding to FFAR2 [123]. These two molecules have favorable effects, decreasing insulin resistance and the functionality of $\beta$-cells [123]. An increase in Bifidobacterium spp. in mice has been linked to have anti-inflammatory effect through the production of GLP2 and reducing intestinal permeability [124]. These are just a few examples on the potential impact of gut microbiota on the development of T2D.

\section{Conclusions}

In conclusion, overwhelming evidence is available highlighting the important role of gut microbiota in key metabolic diseases impacting key pathways like energy homeostasis and inflammation. Changes in life style that involves increased food consumption and reduced exercise in addition to gut microbiota contribute more to metabolic diseases. As a result, better understanding and utilization of various prebiotic and probiotic bacteria may prove to be beneficial in the treatment of metabolic diseases in the future.

\section{Authors' contributions}

OB: Literature search and wrote manuscript. MZ: Literature search and wrote manuscript. OB and MZ: These authors contributed equally to the paper. IT: Critically revised the manuscript. KB: critically revised the manuscript, JA: Critically revised the manuscript. MA: Literature search and wrote manuscript, critically revised the manuscript. All authors read and approved the final manuscript.

\section{Competing interest}

None of the authors have been paid to write this article by a pharmaceutical company or other agency. None of the authors (OB, MZ, IT, JA and MA) have any conflict of interest or anything to disclose.

\section{Author details}

${ }^{1}$ Department of Biochemistry, King Abdul Aziz University, Jeddah, Saudi Arabia. ${ }^{2}$ Faculty of Medicine, Aljouf University, Aljouf, Saudi Arabia. ${ }^{3}$ Biochemistry and Molecular Biology Unit, Dasman Diabetes Institute, Dasman, P.O. Box 118015462 Kuwait City, Kuwait.

Received: 1 April 2016 Accepted: 15 June 2016

Published online: 18 June 2016

\section{References}

1. Ferrante D, Linetzky B, Ponce M, Goldberg L, Konfino J, Laspiur S. Prevalence of overweight, obesity, physical activity and tobacco use in Argentine youth: Global School-Based Student Health Survey and Global Youth Tobacco Survey, 2007-2012. Arch Argent Pediatr. 2014;112:496-503.

2. Rivas-Marino G, Negin J, Salinas-Rodriguez A, Manrique-Espinoza B, Sterner KN, Snodgrass J, Kowal P. Prevalence of overweight and obesity in older Mexican adults and its association with physical activity and related factors: An analysis of the study on global ageing and adult health. Am J Hum Biol. 2015;27:326-33.

3. Morgen CS, Sorensen TI. Obesity: global trends in the prevalence of overweight and obesity. Nat Rev Endocrinol. 2014;10:513-4.

4. McPherson K. Reducing the global prevalence of overweight and obesity. Lancet. 2014;384:728-30.

5. Ng M, Fleming T, Robinson M, Thomson B, Graetz N, Margono C, Mullany EC, Biryukov S, Abbafati C, Abera SF, et al. Global, regional, and national prevalence of overweight and obesity in children and adults during 1980-2013: a systematic analysis for the Global Burden of Disease Study 2013. Lancet. 2014:384:766-81.

6. Quelly SB, Lieberman LS. Global prevalence of overweight and obesity in preschoolers. Anthropol Anz. 2011;68:437-56.

7. de Onis M, Blossner M, Borghi E. Global prevalence and trends of overweight and obesity among preschool children. Am J Clin Nutr. 2010;92:1257-64.

8. Jebb SA, Moore MS. Contribution of a sedentary lifestyle and inactivity to the etiology of overweight and obesity: current evidence and research issues. Med Sci Sports Exerc. 1999:31:5534-541.

9. Mayer-Davis EJ, Costacou T. Obesity and sedentary lifestyle: modifiable risk factors for prevention of type 2 diabetes. Curr Diab Rep. 2001;1:170-6.

10. Hu FB. Sedentary lifestyle and risk of obesity and type 2 diabetes. Lipids. 2003:38:103-8

11. Cox AJ, West NP, Cripps AW. Obesity, inflammation, and the gut microbiota. Lancet Diabetes Endocrinol. 2015;3:207-15.

12. Rosenbaum M, Knight $R$, Leibel RL. The gut microbiota in human energy homeostasis and obesity. Trends Endocrinol Metab. 2015;26(9):493-501.

13. Tai $N$, Wong FS, Wen $L$. The role of gut microbiota in the development of type 1, type 2 diabetes mellitus and obesity. Rev Endocr Metab Disord. 2015;16:55-65.

14. Villanueva-Millan MJ, Perez-Matute P, Oteo JA. Gut microbiota: a key player in health and disease. A review focused on obesity. J Physiol Biochem. 2015; 71(3):509-25.

15. Ley RE, Backhed F, Turnbaugh P, Lozupone CA, Knight RD, Gordon Jl. Obesity alters gut microbial ecology. Proc Natl Acad Sci U S A. 2005;102:11070-5. 
16. Murphy EF, Cotter PD, Healy S, Marques TM, O'Sullivan O, Fouhy F, Clarke SF, O'Toole PW, Quigley EM, Stanton C, et al. Composition and energy harvesting capacity of the gut microbiota: relationship to diet, obesity and time in mouse models. Gut. 2010;59:1635-42.

17. Turnbaugh PJ, Ley RE, Mahowald MA, Magrini V, Mardis ER, Gordon Jl. An obesity-associated gut microbiome with increased capacity for energy harvest. Nature. 2006;444:1027-31

18. Cani PD, Osto M, Geurts L, Everard A. Involvement of gut microbiota in the development of low-grade inflammation and type 2 diabetes associated with obesity. Gut Microbes. 2012;3:279-88.

19. Kallus SJ, Brandt LJ. The intestinal microbiota and obesity. J Clin Gastroenterol. 2012;46:16-24.

20. Cox LM, Blaser MJ. Pathways in microbe-induced obesity. Cell Metab. 2013 17:883-94.

21. Park S, Bae JH. Probiotics for weight loss: a systematic review and meta-analysis. Nutr Res. 2015;35:566-75.

22. Prados-Bo A, Gomez-Martinez S, Nova E, Marcos A. [Role of probiotics in obesity management]. Nutr Hosp. 2015;31 Suppl 1:10-8.

23. Razmpoosh E, Javadi M, Ejtahed HS, Mirmiran P: Probiotics as beneficial agents in the management of diabetes mellitus: a systematic review. Diabetes Metab Res Rev. 2016;32(2):143-68.

24. Dominguez-Bello MG, Costello EK, Contreras M, Magris M, Hidalgo G, Fiere $\mathrm{N}$, Knight R. Delivery mode shapes the acquisition and structure of the initial microbiota across multiple body habitats in newborns. Proc Natl Acad Sci U S A. 2010;107:11971-5.

25. Tanaka S, Kobayashi T, Songjinda P, Tateyama A, Tsubouchi M, Kiyohara C, Shirakawa T, Sonomoto K, Nakayama J. Influence of antibiotic exposure in the early postnatal period on the development of intestinal microbiota. FEMS Immunol Med Microbiol. 2009;56:80-7.

26. Salminen S, Gibson GR, McCartney AL, Isolauri E. Influence of mode of delivery on gut microbiota composition in seven year old children. Gut. 2004:53:1388-9.

27. Makino H, Kushiro A, Ishikawa E, Kubota H, Gawad A, Sakai T, Oishi K, Martin R, Ben-Amor K, Knol J, Tanaka R. Mother-to-infant transmission of intestinal bifidobacterial strains has an impact on the early development of vaginally delivered infant's microbiota. PLoS One. 2013;8:e78331.

28. Munyaka PM, Khafipour E, Ghia JE. External influence of early childhood establishment of gut microbiota and subsequent health implications. Front Pediatr. 2014;2:109.

29. Tlaskalova-Hogenova H, Stepankova R, Kozakova H, Hudcovic T, Vannucci L, Tuckova L, Rossmann P, Hrncir T, Kverka M, Zakostelska Z, et al. The role of gut microbiota (commensal bacteria) and the mucosal barrier in the pathogenesis of inflammatory and autoimmune diseases and cancer: contribution of germ-free and gnotobiotic animal models of human diseases. Cell Mol Immunol. 2011;8:110-20.

30. Ji B, Nielsen J. From next-generation sequencing to systematic modeling of the gut microbiome. Front Genet. 2015;6:219.

31. Thuny F, Richet H, Casalta JP, Angelakis E, Habib G, Raoult D. Vancomycin treatment of infective endocarditis is linked with recently acquired obesity. PLoS One. 2010;5:e9074.

32. Saari A, Virta LJ, Sankilampi U, Dunkel L, Saxen H. Antibiotic exposure in infancy and risk of being overweight in the first 24 months of life. Pediatrics. 2015;135:617-26.

33. Keeney KM, Yurist-Doutsch S, Arrieta MC, Finlay BB. Effects of antibiotics on human microbiota and subsequent disease. Annu Rev Microbiol. 2014;68:217-35

34. Panda S, El khader I, Casellas F, Lopez Vivancos J, Garcia Cors M, Santiago A, Cuenca S, Guarner F, Manichanh C. Short-term effect of antibiotics on human gut microbiota. PLoS One. 2014;9:e95476.

35. Zhang Y, Limaye PB, Renaud HJ, Klaassen CD. Effect of various antibiotics on modulation of intestinal microbiota and bile acid profile in mice. Toxicol Appl Pharmacol. 2014;277:138-45

36. Szych J, Wolkowicz T, La Ragione R, Madajczak G. Impact of antibiotics on the intestinal microbiota and on the treatment of Shiga-toxin-producing Escherichia coli and Salmonella infections. Curr Pharm Des. 2014;20:4535-48.

37. Angelakis $E$, Merhej $V$, Raoult D. Related actions of probiotics and antibiotics on gut microbiota and weight modification. Lancet Infect Dis. 2013;13:889-99.

38. Aguilera M, Vergara P, Martinez V. Stress and antibiotics alter luminal and wall-adhered microbiota and enhance the local expression of visceral sensory-related systems in mice. Neurogastroenterol Motil. 2013;25:e515-529.
39. Tian B, Fadhil NH, Powell JE, Kwong WK, Moran NA: Long-term exposure to antibiotics has caused accumulation of resistance determinants in the gut microbiota of honeybees. MBio. 2012;3(6):e00377-12.

40. Ray K. Gut microbiota: adding weight to the microbiota's role in obesityexposure to antibiotics early in life can lead to increased adiposity. Nat Rev Endocrinol. 2012:8:623.

41. Ubeda C, Pamer EG. Antibiotics, microbiota, and immune defense. Trends Immunol. 2012;33:459-66.

42. Quigley EM. Therapies aimed at the gut microbiota and inflammation: antibiotics, prebiotics, probiotics, synbiotics, anti-inflammatory therapies. Gastroenterol Clin North Am. 2011:40:207-22.

43. lapichino G, Callegari ML, Marzorati S, Cigada M, Corbella D, Ferrari S, Morelli L. Impact of antibiotics on the gut microbiota of critically ill patients. J Med Microbiol. 2008;57:1007-14.

44. Modi SR, Collins JJ, Relman DA. Antibiotics and the gut microbiota. J Clin Invest. 2014;124:4212-8.

45. Jakobsson HE, Jernberg C, Andersson AF, Sjolund-Karlsson M, Jansson JK, Engstrand L. Short-term antibiotic treatment has differing long-term impacts on the human throat and gut microbiome. PLoS One. 2010:5:e9836.

46. Maukonen J, Saarela M. Human gut microbiota: does diet matter? Proc Nutr Soc. 2015;74:23-36.

47. Wu GD, Bushmanc FD, Lewis JD. Diet, the human gut microbiota, and IBD. Anaerobe. 2013:24:117-20.

48. Rothe M, Blaut M. Evolution of the gut microbiota and the influence of diet. Benef Microbes. 2013:4:31-7.

49. Scott KP, Gratz SW, Sheridan PO, Flint HJ, Duncan SH. The influence of diet on the gut microbiota. Pharmacol Res. 2013;69:52-60.

50. Moreira AP, Texeira TF, Ferreira AB, Peluzio Mdo C, Alfenas Rde C. Influence of a high-fat diet on gut microbiota, intestinal permeability and metabolic endotoxaemia. Br J Nutr. 2012;108:801-9.

51. Clarke SF, Murphy EF, Nilaweera K, Ross PR, Shanahan F, OToole PW, Cotter PD. The gut microbiota and its relationship to diet and obesity: new insights. Gut Microbes. 2012;3:186-202.

52. Wong JM, Esfahani A, Singh N, Villa CR, Mirrahimi A, Jenkins DJ, Kendall CW Gut microbiota, diet, and heart disease. J AOAC Int. 2012;95:24-30.

53. Brown K, DeCoffe D, Molcan E, Gibson DL. Diet-induced dysbiosis of the intestinal microbiota and the effects on immunity and disease. Nutrients. 2012:4:1095-119.

54. Pozo-Rubio T, Mujico JR, Marcos A, Puertollano E, Nadal I, Sanz Y, Nova E. Immunostimulatory effect of faecal Bifidobacterium species of breast-fed and formula-fed infants in a peripheral blood mononuclear cell/Caco-2 co-culture system. Br J Nutr. 2011;106:1216-23.

55. Roger LC, Costabile A, Holland DT, Hoyles L, McCartney AL. Examination of faecal Bifidobacterium populations in breast- and formula-fed infants during the first 18 months of life. Microbiology. 2010;156:3329-41.

56. Chen J, Cai W, Feng Y. Development of intestinal bifidobacteria and lactobacilli in breast-fed neonates. Clin Nutr. 2007:26:559-66.

57. Rubaltelli FF, Biadaioli R, Pecile P, Nicoletti P. Intestinal flora in breast- and bottle-fed infants. J Perinat Med. 1998:26:186-91.

58. Benno Y, Sawada K, Mitsuoka T. The intestinal microflora of infants: composition of fecal flora in breast-fed and bottle-fed infants. Microbiol Immunol. 1984;28:975-86.

59. Yoshioka H, Iseki K, Fujita K. Development and differences of intestinal flora in the neonatal period in breast-fed and bottle-fed infants. Pediatrics. 1983;72:317-21.

60. Jones ML, Martoni CJ, Prakash S. Cholesterol lowering and inhibition of sterol absorption by Lactobacillus reuteri NCIMB 30242: a randomized controlled trial. Eur J Clin Nutr. 2012;66:1234-41.

61. Gibson GR, Roberfroid MB. Dietary modulation of the human colonic microbiota: introducing the concept of prebiotics. J Nutr. 1995;125:1401-12.

62. Gibson GR, Probert HM, Loo JV, Rastall RA, Roberfroid MB. Dietary modulation of the human colonic microbiota: updating the concept of prebiotics. Nutr Res Rev. 2004;17:259-75.

63. Macfarlane GT, Steed H, Macfarlane S. Bacterial metabolism and healthrelated effects of galacto-oligosaccharides and other prebiotics. J Appl Microbiol. 2008;104:305-44.

64. De los Reyes-Gavilan CG, Delzenne NM, Gonzalez S, Gueimonde M, Salazar N. Development of functional foods to fight against obesity Opportunities for probiotics and prebiotics. Agro Food Ind Hi Tech. 2014;25:35-9.

65. Turnbaugh PJ, Ridaura VK, Faith JJ, Rey FE, Knight R, Gordon Jl. The effect of diet on the human gut microbiome: a metagenomic analysis in humanized gnotobiotic mice. Sci Transl Med. 2009;1:6ra14. 
66. Bruce-Keller AJ, Salbaum JM, Luo M, Blanchard E, Taylor CM, Welsh DA, Berthoud HR. Obese-type gut microbiota induce neurobehavioral changes in the absence of obesity. Biol Psychiatry. 2015;77:607-15.

67. Tsai YT, Cheng PC, Pan TM. Anti-obesity effects of gut microbiota are associated with lactic acid bacteria. Appl Microbiol Biotechnol. 2014;98:1-10.

68. Boroni Moreira AP, Fiche Salles Teixeira T, do C Gouveia Peluzio M, de Cassia Goncalves Alfenas R. Gut microbiota and the development of obesity. Nutr Hosp. 2012;27:1408-14.

69. Tagliabue A, Elli M. The role of gut microbiota in human obesity: recent findings and future perspectives. Nutr Metab Cardiovasc Dis. 2013;23:160-8.

70. Murphy EF, Cotter PD, Hogan A, O'Sullivan O, Joyce A, Fouhy F, Clarke SF, Marques TM, O'Toole PW, Stanton C, et al. Divergent metabolic outcomes arising from targeted manipulation of the gut microbiota in diet-induced obesity. Gut. 2013;62:220-6.

71. Flint HJ. Obesity and the gut microbiota. J Clin Gastroenterol. 2011; 45(Suppl):S128-132.

72. Delzenne NM, Neyrinck AM, Backhed F, Cani PD. Targeting gut microbiota in obesity: effects of prebiotics and probiotics. Nat Rev Endocrinol. 2011;7:639-46.

73. Scarpellini E, Campanale M, Leone D, Purchiaroni F, Vitale G, Lauritano EC, Gasbarrini A. Gut microbiota and obesity. Intern Emerg Med. 2010;5 Suppl 1:S53-56

74. Musso G, Gambino R, Cassader M. Obesity, diabetes, and gut microbiota: the hygiene hypothesis expanded? Diabetes Care. 2010;33:2277-84

75. Cani PD, Delzenne NM. Involvement of the gut microbiota in the development of low grade inflammation associated with obesity: focus on this neglected partner. Acta Gastroenterol Belg. 2010;73:267-9.

76. Zhang H, DiBaise JK, Zuccolo A, Kudrna D, Braidotti M, Yu Y, Parameswaran $P$, Crowell MD, Wing R, Rittmann BE, Krajmalnik-Brown R. Human gut microbiota in obesity and after gastric bypass. Proc Natl Acad Sci U S A. 2009;106:2365-70.

77. Cani PD, Bibiloni R, Knauf C, Waget A, Neyrinck AM, Delzenne NM, Burcelin R. Changes in gut microbiota control metabolic endotoxemia-induced inflammation in high-fat diet-induced obesity and diabetes in mice. Diabetes. 2008;57:1470-81.

78. Tremaroli V, Karlsson F, Werling M, Stahlman M, Kovatcheva-Datchary P, Olbers T, Fandriks L, le Roux CW, Nielsen J, Backhed F. Roux-en-Y gastric bypass and vertical banded gastroplasty induce long-term changes on the human gut microbiome contributing to fat mass regulation. Cell Metab. 2015;22:228-38

79. Lutz TA, Bueter M. Physiological mechanisms behind Roux-en-Y gastric bypass surgery. Dig Surg. 2014;31:13-24.

80. Osto M, Abegg K, Bueter M, le Roux CW, Cani PD, Lutz TA. Roux-en-Y gastric bypass surgery in rats alters gut microbiota profile along the intestine. Physiol Behav. 2013;119:92-6.

81. Kugelberg E. Surgery: Altered gut microbiota trigger weight loss. Nat Rev Endocrinol. 2013;9:314.

82. Kong LC, Tap J, Aron-Wisnewsky J, Pelloux V, Basdevant A, Bouillot JL, Zucker JD, Dore J, Clement K. Gut microbiota after gastric bypass in human obesity: increased richness and associations of bacterial genera with adipose tissue genes. Am J Clin Nutr. 2013;98:16-24.

83. Graessler J, Qin Y, Zhong H, Zhang J, Licinio J, Wong ML, Xu A, Chavakis T, Bornstein $A B$, Ehrhart-Bornstein $M$, et al. Metagenomic sequencing of the human gut microbiome before and after bariatric surgery in obese patients with type 2 diabetes: correlation with inflammatory and metabolic parameters. Pharmacogenomics J. 2013;13:514-22.

84. Bueter M, Abegg K, Seyfried F, Lutz TA, le Roux CW: Roux-en-Y gastric bypass operation in rats. J Vis Exp 2012:e3940.

85. Aron-Wisnewsky J, Dore J, Clement K. The importance of the gut microbiota after bariatric surgery. Nat Rev Gastroenterol Hepatol. 2012;9:590-8.

86. Woodard GA, Encarnacion B, Downey JR, Peraza J, Chong K, HernandezBoussard T, Morton JM. Probiotics improve outcomes after Roux-en- $Y$ gastric bypass surgery: a prospective randomized trial. J Gastrointest Surg. 2009;13:1198-204.

87. Liou AP, Paziuk M, Luevano Jr JM, Machineni S, Turnbaugh PJ, Kaplan LM. Conserved shifts in the gut microbiota due to gastric bypass reduce host weight and adiposity. Sci Transl Med. 2013;5:178ra141.

88. Gao Z, Yin J, Zhang J, Ward RE, Martin RJ, Lefevre M, Cefalu WT, Ye J. Butyrate improves insulin sensitivity and increases energy expenditure in mice. Diabetes. 2009:58:1509-17.

89. Lin HV, Frassetto A, Kowalik Jr EJ, Nawrocki AR, Lu MM, Kosinski JR, Hubert JA, Szeto D, Yao X, Forrest G, Marsh DJ. Butyrate and propionate protect against diet-induced obesity and regulate gut hormones via free fatty acid receptor 3-independent mechanisms. PLoS One. 2012;7:e35240.

90. Yamashita H, Fujisawa K, Ito E, Idei S, Kawaguchi N, Kimoto M, Hiemori M, Tsuji H. Improvement of obesity and glucose tolerance by acetate in Type 2 diabetic Otsuka Long-Evans Tokushima Fatty (OLETF) rats. Biosci Biotechnol Biochem. 2007;71:1236-43.

91. Fernandes J, Su W, Rahat-Rozenbloom S, Wolever TM, Comelli EM. Adiposity, gut microbiota and faecal short chain fatty acids are linked in adult humans. Nutr Diabetes. 2014;4:e121.

92. Schwiertz A, Taras D, Schafer K, Beijer S, Bos NA, Donus C, Hardt PD. Microbiota and SCFA in lean and overweight healthy subjects. Obesity (Silver Spring). 2010;18:190-5.

93. den Besten G, van Eunen K, Groen AK, Venema K, Reijngoud DJ, Bakker BM. The role of short-chain fatty acids in the interplay between diet, gut microbiota, and host energy metabolism. J Lipid Res. 2013;54(9):2325-40.

94. Nohr MK, Pedersen MH, Gille A, Egerod KL, Engelstoft MS, Husted AS, Sichlau RM, Grunddal KV, Poulsen SS, Han S, et al. GPR41/FFAR3 and GPR43/ FFAR2 as cosensors for short-chain fatty acids in enteroendocrine cells vs FFAR3 in enteric neurons and FFAR2 in enteric leukocytes. Endocrinology. 2013;154:3552-64

95. Tolhurst G, Heffron H, Lam YS, Parker HE, Habib AM, Diakogiannaki E, Cameron J, Grosse J, Reimann F, Gribble FM. Short-chain fatty acids stimulate glucagon-like peptide-1 secretion via the G-protein-coupled receptor FFAR2. Diabetes. 2012;61:364-71.

96. Kasubuchi M, Hasegawa S, Hiramatsu T, Ichimura A, Kimura I. Dietary gut microbial metabolites, short-chain fatty acids, and host metabolic regulation. Nutrients. 2015;7:2839-49.

97. Kimura I, Inoue D, Hirano K, Tsujimoto G. The SCFA receptor GPR43 and energy metabolism. Front Endocrinol (Lausanne). 2014;5:85.

98. Bjursell M, Admyre T, Goransson M, Marley AE, Smith DM, Oscarsson J, Bohlooly YM. Improved glucose control and reduced body fat mass in free fatty acid receptor 2-deficient mice fed a high-fat diet. Am J Physiol Endocrinol Metab. 2011;300:E211-220.

99. Kimura I, Ozawa K, Inoue D, Imamura T, Kimura K, Maeda T, Terasawa K, Kashihara D, Hirano K, Tani T, et al. The gut microbiota suppresses insulinmediated fat accumulation via the short-chain fatty acid receptor GPR43. Nat Commun. 2013:4:1829.

100. Chambers ES, Morrison DJ, Frost G. Control of appetite and energy intake by SCFA: what are the potential underlying mechanisms? Proc Nutr Soc. 2015;74:328-36

101. Kaji I, Karaki S, Kuwahara A. Short-chain fatty acid receptor and its contribution to glucagon-like peptide-1 release. Digestion. 2014;89:31-6.

102. Conterno L, Fava F, Viola R, Tuohy KM. Obesity and the gut microbiota: does up-regulating colonic fermentation protect against obesity and metabolic disease? Genes Nutr. 2011;6:241-60.

103. Ye D, Li FY, Lam KS, Li H, Jia W, Wang Y, Man K, Lo CM, Li X, Xu A. Toll-like receptor-4 mediates obesity-induced non-alcoholic steatohepatitis through activation of X-box binding protein-1 in mice. Gut. 2012;61:1058-67.

104. Kim SJ, Choi Y, Choi YH, Park T. Obesity activates toll-like receptor-mediated proinflammatory signaling cascades in the adipose tissue of mice. J Nutr Biochem. 2012;23:113-22.

105. Karagiannides I, Pothoulakis C. Obesity, innate immunity and gut inflammation. Curr Opin Gastroenterol. 2007;23:661-6.

106. Creely SJ, McTernan PG, Kusminski CM, Fisher f M, Da Silva NF, Khanolkar M, Evans M, Harte AL, Kumar S. Lipopolysaccharide activates an innate immune system response in human adipose tissue in obesity and type 2 diabetes. Am J Physiol Endocrinol Metab. 2007;292:E740-747.

107. Rodes L, Khan A, Paul A, Coussa-Charley M, Marinescu D, TomaroDuchesneau C, Shao W, Kahouli I, Prakash S. Effect of probiotics Lactobacillus and Bifidobacterium on gut-derived lipopolysaccharides and inflammatory cytokines: an in vitro study using a human colonic microbiota model. J Microbiol Biotechnol. 2013;23:518-26.

108. Gulden E, Wong FS, Wen L. The gut microbiota and Type 1 Diabetes. Clin Immunol. 2015;159(2):143-53.

109. Murri M, Leiva I, Gomez-Zumaquero JM, Tinahones FJ, Cardona F, Soriguer F, Queipo-Ortuno MI. Gut microbiota in children with type 1 diabetes differs from that in healthy children: a case-control study. BMC Med. 2013;11:46.

110. Brown CT, Davis-Richardson AG, Giongo A, Gano KA, Crabb DB, Mukherjee N, Casella G, Drew JC, Ilonen J, Knip M, et al. Gut microbiome metagenomics 
analysis suggests a functional model for the development of autoimmunity for type 1 diabetes. PLoS One. 2011;6:e25792.

111. Wen L, Ley RE, Volchkov PY, Stranges PB, Avanesyan L, Stonebraker AC, Hu C, Wong FS, Szot GL, Bluestone JA, et al. Innate immunity and intestinal microbiota in the development of Type 1 diabetes. Nature. 2008;455:1109-13.

112. Lucas K, Maes M. Role of the Toll Like receptor (TLR) radical cycle in chronic inflammation: possible treatments targeting the TLR4 pathway. Mol Neurobiol. 2013;48:190-204.

113. Atkinson MA, Chervonsky A. Does the gut microbiota have a role in type 1 diabetes? Early evidence from humans and animal models of the disease. Diabetologia. 2012;55:2868-77.

114. Burrows MP, Volchkov P, Kobayashi KS, Chervonsky AV. Microbiota regulates type 1 diabetes through Toll-like receptors. Proc Natl Acad Sci U S A. 2015;112:9973-7.

115. Hara N, Alkanani AK, Ir D, Robertson CE, Wagner BD, Frank DN, Zipris D. The role of the intestinal microbiota in type 1 diabetes. Clin Immunol. 2013;146:112-9.

116. King C, Sarvetnick N. The incidence of type-1 diabetes in NOD mice is modulated by restricted flora not germ-free conditions. PLoS One. 2011;6:e17049.

117. Marietta EV, Gomez AM, Yeoman C, Tilahun AY, Clark CR, Luckey DH, Murray JA, White BA, Kudva YC, Rajagopalan G. Low incidence of spontaneous type 1 diabetes in non-obese diabetic mice raised on gluten-free diets is associated with changes in the intestinal microbiome. PLoS One. 2013;8:e78687.

118. Mathis D, Benoist C. The influence of the microbiota on type-1 diabetes: on the threshold of a leap forward in our understanding. Immunol Rev. 2012;245:239-49.

119. Vaarala O. The gut as a regulator of early inflammation in type 1 diabetes. Curr Opin Endocrinol Diabetes Obes. 2011;18:241-7.

120. Vaarala O. Human intestinal microbiota and type 1 diabetes. Curr Diab Rep. 2013;13:601-7.

121. Vaarala O, Atkinson MA, Neu J. The "perfect storm" for type 1 diabetes: the complex interplay between intestinal microbiota, gut permeability, and mucosal immunity. Diabetes. 2008;57:2555-62.

122. Yang C, Fei Y, Qin Y, Luo D, Yang S, Kou X, Zi Y, Deng T, Jin M. Bacterial Flora Changes in Conjunctiva of Rats with Streptozotocin-Induced Type I Diabetes. PLoS One. 2015;10:e0133021.

123. Cani PD, Delzenne NM. The role of the gut microbiota in energy metabolism and metabolic disease. Curr Pharm Des. 2009;15:1546-58.

124. Cani PD, Possemiers S, Van de Wiele T, Guiot Y, Everard A, Rottier O, Geurts $L$, Naslain D, Neyrinck A, Lambert DM, et al. Changes in gut microbiota control inflammation in obese mice through a mechanism involving GLP-2-driven improvement of gut permeability. Gut. 2009;58:1091-103.

125. Qin J, Li Y, Cai Z, Li S, Zhu J, Zhang F, Liang S, Zhang W, Guan 1 Y, Shen D, et al. A metagenome-wide association study of gut microbiota in type 2 diabetes. Nature. 2012;490:55-60.

126. Amyot J, Semache M, Ferdaoussi M, Fontes G, Poitout V. Lipopolysaccharides impair insulin gene expression in isolated islets of Langerhans via Toll-Like Receptor-4 and NF-kappaB signalling. PLoS One. 2012;7:e36200

127. Caricilli AM, Picardi PK, de Abreu LL, Ueno M, Prada PO, Ropelle ER, Hirabara SM, Castoldi A, Vieira P, Camara NO, et al. Gut microbiota is a key modulator of insulin resistance in TLR 2 knockout mice. PLoS Biol. 2011;9:e1001212.

128. Dali-Youcef $N$, Mecili M, Ricci $R$, Andres E. Metabolic inflammation: connecting obesity and insulin resistance. Ann Med. 2013;45:242-53.

129. Tanti JF, Ceppo F, Jager J, Berthou F. Implication of inflammatory signaling pathways in obesity-induced insulin resistance. Front Endocrinol (Lausanne). 2012;3:181.

130. Hamilton MK, Boudry G, Lemay DG, Raybould HE. Changes in intestinal barrier function and gut microbiota in high-fat diet-fed rats are dynamic and region dependent. Am J Physiol Gastrointest Liver Physiol. 2015;308: G840-851

131. Kim KA, Gu W, Lee IA, Joh EH, Kim DH. High fat diet-induced gut microbiota exacerbates inflammation and obesity in mice via the TLR4 signaling pathway. PLoS One. 2012;7:e47713.

132. Chen D, Yang Z, Chen X, Huang Y, Yin B, Guo F, Zhao H, Huang J, Wu Y, Gu R. Effect of Lactobacillus rhamnosus hsryfm 1301 on the Gut Microbiota and Lipid Metabolism in Rats Fed a High-Fat Diet. J Microbiol Biotechnol. 2015;25:687-95.

133. de La Serre CB, Ellis CL, Lee J, Hartman AL, Rutledge JC, Raybould HE. Propensity to high-fat diet-induced obesity in rats is associated with changes in the gut microbiota and gut inflammation. Am J Physiol Gastrointest Liver Physiol. 2010;299:G440-448.
134. Zimmer J, Lange B, Frick JS, Sauer H, Zimmermann K, Schwiertz A, Rusch K, Klosterhalfen $\mathrm{S}$, Enck $\mathrm{P}$. A vegan or vegetarian diet substantially alters the human colonic faecal microbiota. Eur J Clin Nutr. 2012;66:53-60.

135. Kim MS, Hwang SS, Park EJ, Bae JW. Strict vegetarian diet improves the risk factors associated with metabolic diseases by modulating gut microbiota and reducing intestinal inflammation. Environ Microbiol Rep. 2013;5:765-75.

136. De Filippo C, Cavalieri D, Di Paola M, Ramazzotti M, Poullet JB, Massart S, Collini S, Pieraccini G, Lionetti P. Impact of diet in shaping gut microbiota revealed by a comparative study in children from Europe and rural Africa. Proc Natl Acad Sci U S A. 2010;107:14691-6.

137. Zhang C, Li S, Yang L, Huang P, Li W, Wang S, Zhao G, Zhang M, Pang X, Yan Z, et al. Structural modulation of gut microbiota in life-long calorierestricted mice. Nat Commun. 2013:4:2163.

\section{Submit your next manuscript to BioMed Central and we will help you at every step:}

- We accept pre-submission inquiries

- Our selector tool helps you to find the most relevant journal

- We provide round the clock customer support

- Convenient online submission

- Thorough peer review

- Inclusion in PubMed and all major indexing services

- Maximum visibility for your research

Submit your manuscript at www.biomedcentral.com/submit
Biomed Central 